\title{
Formal Multiple Intelligences Assessment Instruments for 4-6 Years Old Children
}

\author{
MARTINI JAMARIS, EDWITA* \\ School of Education State University of Jakarta INDONESIA \\ *Corresponding author: martinijamaris@yahoo.com
}

Received November 06, 2014; Revised November 26, 2014; Accepted December 03, 2014

\begin{abstract}
This two years research was done in the form of research and development. The selection of the research method was because the research developed valid and reliable instruments which be used to assess eight types of the multiple-intelligences of the 4-6 years old children. They were eight types of multiple intelligences namely verbal/linguistics intelligence, logical mathematical intelligence, visual spatial intelligence, intrapersonal intelligence, interpersonal intelligence, bodily/kinesthetic intelligence, music/rythmic intelligence and naturalist intelligence. The two years research and development was done in three stages. By doing literature research, the first stage was to analyze concepts, principles, and theories aimed to construct multiple intelligences conceptual frame work of the 4-6 years old children. The second stage was to develop valid and reliable eight types of formal multiple intelligences assessment instruments for the 4-6 years old children, in which, the validity and reliability of the assessment instruments were confirmed by field test. First field test was carried out on a small group consisted of 20 children, and the second field test included 40 children. Both field tests revealed that the eight types of multiple intelligences assessment instruments were valid and reliable. The third stage was to assess the improvement of the 46 years old children's multiple intelligences after participating the instructional model focused on the improvement of multiple intelligences. The third stage was done by implementing mix method research and revealed that the children's multiple intelligences were improved. The improvement of the children's multiple intelligences assessed accurately. To decide the level of multiple intelligences improvement of the children, therefore, the assessment instruments equipped by measured standard used.
\end{abstract}

Keywords: valid and reliable, the 4-6 years old children, improvement, assesment instruments, mix method research, measured standard

Cite This Article: MARTINI JAMARIS, and EDWITA, "Formal Multiple Intelligences Assessment Instruments for 4-6 Years Old Children.” American Journal of Educational Research, vol. 2, no. 12 (2014): 11641174. doi: 10.12691/education-2-12-6.

\section{Introduction}

Human being have various abilities, such as, cognitive ability, language and communication ability, psychosocial ability, physical ability, which have to develop, as much as possible since early times. According to Gardner (1993:, xii-xiii) various abilities of the human being, including young children can be seen in the form of various potential developments, including multiple intelligences, which at least consist of eight types of intelligence: (1) logical mathematical, (2) verbal/linguistic (3) visual spatial, (4) bodily kinesthetic, (5) interpersonal (6) intrapersonal (7) rhythmic-musical and (8) naturalist.

Research findings multiple intelligences development of 36 young children, aged 3-5 years old who come from low social economics background revealed that stimulation and intervention done to the young children has increased their multiple intelligences (Martini Jamaris, 2005: 16-17). Furthermore, the research finding of another study on profile of multiple intelligences of the 4-6 years old children in DKI Jakarta, Indonesia, showed that the multiple intelligences of the children in general was classified into normal. The research did not find the children with extreme multiple intelligences, such as, above normal or below normal. (Martini Jamaris, et al, 2012: 96-97). The reasons underlayed to this research results are: (1) limited research sample and (2) instruments used to collect data are needed to be improved. Therefore, in order to have rich scientific information o the young children multiple intelligences, it is necessary to develop formal multiple intelligences assessment instruments, especially for the 4-6 years old children.

Multiple intelligences development is one of the efforts to build the young children future development foundations. In accordance with the need in developing the formal multiple intelligences assessment instruments for the 4-6 years old children, there were several questions identified, as followed: (1) how to identify the eight types of multiple intelligences of the 4-6 years old children?; (2) what kind of concepts and theories could be proof and used to identify the characteristics of the eight types of multiple intelligences of the 4-6 years old children?; (3) what kind of instruments could be used to assess the eight types of multiple intelligences of the 4-6 years old children? 
(4) how to develop the eight types of formal multiple intelligences assessment instruments to assess the multiple intelligences of the 4-6 years old children?; (5) how to implement the eight types of formal multiple intelligences assessment instruments of the 4-6 years old children, in an instructional process, in order to know the effectiveness of the assessment instruments in assessing the 4-6 years old children's multiple intelligences improvement?

The research result was expected to come out with some innovations of applied technologies in the field of early childhood education. Therefore, the advantages of the research findings are: (1) to enlarge the concepts and theories of multiple intelligences, particularly, multiple intelligences of the 4-6 years ol childre; (2) to have eight types valid and reliable formal assessment instruments of multiple intelligences, especially for the 4-6 years old children; (3) the research finding could be used by other researchers to do depth research on multiple intelligences of the 4-6 years old children, or other group of children.

Cross analysis theories which was done for this research were mainly consisted of: (1) cross analysis of intelligences theories and (2) cross analysis of multiple intelligence theories.

\section{Intelligence Theories Analysis}

Martini Jamaris (2011: 122) explained that intelligence was mental activities which leaded to self adaptation, to select and to build environment which was suitable for the living of the related individual. In accordance with this statement, Papalia \& Old (1986: 237) stated that intelligence was the result interaction among the abilities and experiences of the individuals with their environment. The result of the interaction are the ability of individuals to remember, to understand the meaning of various concrete and abstract concepts, understand the relation among objects, events, ideas, as well as the abilities to solve various problems. Gardner (1993: 67-68) declared that intelligence was not consisted of a single substance but consisted of multiple substances. Therefore, he called them multiple intelligences.

Multiple intelligences were the innovation in the field of intelligence which found by Howard Gardner (1993: xii-xiii). Some reasons related to his finding, were isolation potential brain damages. Based on the research finding done by Gardner and his colleagues, it could be mentioned that if a person experience brain damage, the damage would influence on the brain functions. For example, if the person experience damage in the front part of his brain, he would have problems in doing activities related to speech and language, reading and writing, but he still able to do some other activities, such as, mathematics, singing, dancing, and communicating with others. The previous statements were supported by $\mathrm{Li}$ (1996) which cited by Martini Jamaris (2013: 99), "the brain has special maps which related to the brain functions. If the brain is damaged, consequently, the brain functions related to the damage are not running or function well.”

Piaget (1971: 49: 91, 1985: 60) explained that cognitive ability or the ability to think was developed through several stages, as followed: (1) sensomotor, 0-2 years old, (2) preoperational, 2-7 years old, (3) concrete operation, 7-12 years old and (4) formal operation, 12 years old until adults. Furthermore Gardner (1983:68) concluded that there were at least seven self government regions of the brains which influence the existed of super child. Consequently, if the child has high intelligence function in the certain brain function, he will be weak in other brain functions. For example, if the child has high logical mathematics, he will be weak in the field of language and communication.

Multiple intelligences had been possed by human being before century. A long with the facts, the existence of multiple intelligences were supported by psychometrics findings. It could be seen by psychological test, particularly, IQ test, which dig up information and vocabularies abilities of an individual. Various findings in experimental psychology showed that individuals who posses specific ability in reading, did not mean that he could authomatically transfer his ability to the logical mathematical ability. Beside that, there was a serial operation functions of each intelligence, such as, musical / rythmic intelligence, this kind of intelligence was supported by the sensitiveness to differenciate various rytmics structures (Ross, Marshal, Scott, 1999: 11). Furthermore, the intelligence of bodily/kinesthetic was supported by the ability to imitate other's bodily/kinesthetic movements. The same condition also happened with fine motoric movement. Lazaer (2000: 7) stated that multiple intelligences was the latest development in the field of intelligence, in which, the multiple intelligences could explain various aspects which were used by individual to becomes clever.

\section{Multiple Intelligence Theories Analysis}

\subsection{Verbal/Linguistics Intelligence}

Verbal/linguistics intelligence involves sensitiveness toward sound, structure meaning and function of words, as well as, language which are appeared through speak interaction, discussion, and reading. Furthermore, the verbal/linguistic intelligence is also appeared in form of ability to used words effectively, either verbally or non verbally, which includes the ability to manipulate sintac and language structure, fonology, or the verbal /sound of language, semantic or the meaning of words, and the practical used of language (Gardner, 1993: 76 -79, Pohl, 2000: 49, Fograty, 1991: 67). Among the practical used of language is rhetorical ability or the ability to convince others by using language, mnemonic or the ability to used language in order to remember easily, meta-language or the ability of using language for discussing. The indications of the existence of verbal/linguistics abilities are: (1) enjoy speaking, (2) enjoy reading and (3) writing, (4) enjoy listen or deliver story, (5) enjoy to play with words, etc.

Development of verbal linguistic of the 4-6 years old children is develop side by side with language development of the children. Papalia \& Olds (1995: 222, Paplia \&Olds, 1985: 420) mentioned that the language development of the 4-6 years old children went through two phases, as followed: (1) receptive ability or ability of the children to listen and to record sound of language which heard by them, (2) expressive ability or ability to express language and use it for communication, e.g. for showing agree or disagree, and for speaking interaction. 
The 4-6 years olds children's verbal/language intellligence can be identified by their language overt behaviors, among them are: (1) enjoy speaking interaction, (2) tell short or simple story, (3) remember name, place, date, any small things easily, and (4) enjoy reading books (6) like to spell words, like to listen to the poet, (7) enjoy language games, (8) enjoy to listen to the radio, and have good grade in language lesson reading and writing

\subsection{Logical Matematical Intelligence}

Logical mathematical intelligence relates to sensitiveness in looking for pattrens which are used in calculating and abstract thinking, as well, thinking logicaly and scientifically. The existence of this intelligence can be seen in the ability for making systematic argumentation, such as, thinking structurally and logically, as well as, scientifically. Therefore, behavior performanced relates to logical mathematical intelligence are the abilities in making categorization, making classification, making inference and generalization, and calculating, as well as, numeric ability, finding pattrens and testing hyphotesis (Gardner, 1993: 157-159, Pohl, 2000: 49, Fograty, 1991: 67). The 4-6 years old children are in the stage of preoperational (Piaget, 1974: 49-91). Consequently, the logical mathematical intelligence of children involves the ability to identify and to remember objects, events, and people which have been known by the children previously. Furthermore, the children 's logical mathematical intelligence can be seen form their abilities to use their minds, starting from to understandnd the change in weight, the change in size, the change in amount, up to understand numeric concepts and its' symbols, ability in making relation of causes and effects based on size, amount, and shape, ability in grouping objects, events, and people in accordance with their classification, as well as, to understand symbols which containt meaning (Papalia \&Olds 1995: 212-224, Papalia \& Olds 1985: 420).

The 4-6 years old children's logical mathematical intelligence can be identified by their abilities in: (1) classifying objects, events, and people, (2) arranging objects and events based their order / hierarchy (3) making explanation logically and rasionally, (4) remembering numbers up to 10 easily, calculating numbers up to 10 easily, understanding cause and effect relationship, (4) finding pattrens of objects and events, (5) understanding subtraction $(-+)$ proccess up to 10 easily.

\subsection{Visual-Spatial Intelligence}

Visual spatial intelligence relates to sensitiveness in integrating visual perception and thinking, as well as, transferring visual perception into pattren, picture, building design (Gardner 1993: 174-175, Pohl, 2000: 46, Fograty, 1991: 67). Visual spatial involves ability in finding characteristics of objects in environment, which appears in the form of mental picture, detail information, and picture sclapture which involves lines, color, shape, size, and width, as well as, the relationship among those aspects (Glass \& Holyoak, 1986: 140).

The 4-6 years old children's visual-spatial intelligence develops along with their ability to integrate visual perception activities with their cognitive process, as well as, their ability to transfer both of them in the form of lines, colors, shapes, sizes, width and the relationship among those aspects. This process involves visualization ability to express ideas. Visual spatials ability can be seen in the form of matrics and grafics (Martini Jamaris, 2005: 188). Therefore, the 4-6 years old children's visual spatial intelligence can be identified by their ability in: (1) picturing ideas in the form of drawing, (2) picturing events and objects detailly, (3) arranging puzzle, (4) picturing people, animals, objects and events in the form of drawing, (5) arranging blocks into three dimensions contraction or building, (6) understanding picture or illustration easily. and give explanation

\subsection{Bodily - Kinesthetic Intelligence}

Bodily kinesthetic intelligence involves sensitiveness and skill in controlling the movements of gross motor and fine motor, as well as, the movement based on visual motor perception, such as, skill in using tools, running with coordinated movement, skill in doing dancing, sport, swimming, etc. The bodily-kinesthetic intelligence also involves abilities in coordinating body movement, balancing body movement, body strength, movement flexibility, speed movement, tacktile, and haptic ability (Gardner, 1993: 206-212, Pohl, 2000: 49, Fograty, 1991: 67). The bodily -kinesthetic coordination develops a long with the development of gross motor and fine motor development and the ability to integrate the both movement balancely.

Kepheart (1973: 15-17) explained that the ability in coordinating hand and body movement are devided into four dimensions, as followed: (1) posture which involves the ability in coordinating visual perception and visual motor perception. Consequently, the a person can arrange his body position among objects around him; (2) laterality which involves the ability in moving gross motor and fine motor in accordance with direction and goal of the movement; (3) posture and laterality integration are requirement in doing gross motor movement, such as, running, jumping, pushing, throwing, as well as, fine motor movement, such as, writing, drawing, painting, kniting, etc.

Martini Jamaris (2003: 47) explained that the 4-6 years old children are already able to coordinate their body movement well, either gross motor movement or fine motor movements. Therefore, it can be concluded that bodily -kinesthetic intelligence of the 4-6 years old children can be identified by their abilities in: (1) riding three wheel cycles or two wheel cycles, (2) running and suddenly stop, (3) climbing, (4) hoping with one foot and two feet, (5) jumping, (6) standing balancely on one foot, (7) walking on bridge or block balancely, etc. On the other hands, the fine motor movement of the children can be identified by their ability in: (1) opening and closing box, putting on and putting off dress buttons, holding paper while another hand writing, folding papers into object shape, etc, Therefore, development of the bodily kinesthetic intelligence can be identified by the ability of the 4-6 years old children in using all body movement to express various ideas and feeling, such as, pantonim, dancing, and hands abilities in making picture, sculpting, coordinating hand and visual perception skillfully, such as, a doctor doing surgery activities 


\subsection{Intrapersonal Intelligence}

Intrapersonal intelligence relates to sensitiveness or awareness of doing self evaluation, in which, the person concerned compering her/his strength and weakness to other persons. This type of this multiple intelligences involves some aspects, as followed: (1) awareness of self feeling, (2) awareness of self strength and self weakness, (3) self attention, (4) self motivation, (5) self temperament, and (6) self aspiration, as well as, (7) ability of doing self discipline, (8) self understanding and (9) self confidenced (Gardner, 1993: 237-249, Pohl, 2000: 49, Fogarty, 1991: 67).

Intrapersonal intelligence of the 4-6 years old children is developed a long with their development in understanding themselves. Santrock (1996: 378) stated that intrapersonal intelligence is related to self understanding which shown as self concept. The self concept involves self identity, self difference with other persons. Furthermore, Woolfolk \& McCune-Nicolich (1984: 84) and Martini Jamaris (2011: 42-43) stated that the young children at aged 4-6 years old are in the stage of phycosocial development.. Therefore, the vocal point is self initiative. It means that the children are able to do various activities based on their initiatives. The 4-6 years old children's intrapersonal intelligence can be identified by their overt behaviors, as followed: (1) showing abilities in focusing attention during doing some activities, especially, the activities which based on their initiative, (2) showing free or unstressed behaviors because they have their own point of view, (3) having strong self motivation, (4) showing ability in learning and doing some activities alone, (5) expressing thinking and feeling appropriately, (6) showing ability in self directing toward goal and (7) having some hobbies.

\subsection{Interpersonal Intelligence}

Interpersonal intelligence is awareness to differenciate and to act in response toward overt behavior which shown by other persons. The appearance of this intelligence can be identified by: (1) the ability in initiating communication with others, (2) ability in doing activities cooperatively, (3) liked by others around them, (4) the ability in doing activities in team work (Gardner, 1993: 237-249, Pohl, 2000: 49, Fograty, 1991: 67). Moreover, interpersonal intelligence involves the ability in differentiating and recognizing various manners, certain objective, motivation and feeling of others. This kind of intelligence also involves the ability in interpreting face expressions, sound and body movement of others. Therefore, the persons who are able in doing interaction effectively with others, such as, to convince others to do something or to lead other toward the intended goal, is called as a good interpersonal intelligence persons.

The interpersonal intelligence of the 4-6 years old children develop side by side with psychosocial development. (Martini Jamaris, 2005: 182). Consequently, interpersonal intelligence of the children can be identified by their abilities in: (1) communicating with others which bound in the form of friendship, (2) doing some activities cooperatively, (3) offering some helps to others, and (4) values understanding. Therefore, it can be concluded that the interpersonal intelligence of the 4-6 years old children can be identified by their overt behaviors, as followed: (1) having some friends, (2) making a lot of social activities, either at school or other place in their environment, (3) familiar with their environment, (4) getting involve in various activities at school or out of school, (5) to be able to take action to overcome conflict or dispute among friends, (6) enjoy to play in team, (7) showing empathy to other s' feelings (8) to be able to take action as counselor for friends, (8) enjoy teaching others, (9) show leadership ability.

\subsection{Musical-Rhythmic Intelligence}

Musical and rhythmics intelligence is sensitiveness in listening to sound, (Gardner, 104-105, Pohl, 2000: 49) Musical-rhythmics intelligence is the result of integrated development of cognitive, physical, psychosocial, language and communication (Martini Jamaris, 2005: 183). The 4-6 years old children enjoy listening to the music and other form of arts. Therefore, they are able to express their musical- rhythmic intelligence through various activities which are related to the intelligence expressions. Musicalrhythmic intelligence of the 4-6 years old children can be identified by their overt behaviors, as followed: (1) remember rhythmic and melody easily, (2) to be able to match movement to the sound of music and melody, (3) enjoy playing music instruments, (4) to be able to create rhythmic, (5) enjoy listening to the music.

\subsection{Naturalist Intelligence}

Naturalist intelligence is sensitiveness toward natural environment appreciation. The naturalist intelligence exists as the effect result of the multiple intelligence types integration. The existence of this type of intelligence can be identified by environmental awareness, such as, any activities dealing with environmental conservation (Lazaer, 2000: 73, Pohl, 2000: 49). Hence, the naturalist intelligence of the 4-6 years old children can be identified by their overt behaviors toward environment, such as, (a) enjoy doing environmental conservation, (2) awareness of ecological problems, (3) awareness of natural phenomenas, and (4) enjoy doing natural observation.

\section{Research Method}

This research was done in two years. Consequently, in accordance with the need of the research, the method used was research and development (R \& D) which aimed to develop or to construct formal multiple intelligences assessment instruments, which involved eight types of multiple intelligences of the 4-6 years old children. Gall, Borg and Gall (2003) and Dick and Carey (2009) as cited by Gooch (2012: 88 -111) stated seven steps in doing research and development, as followed; (1) research analysis and need assessment/ proof of concepts; (2) product planning and design; (3) product development; (4) preliminary field test; (5) product revision; (6) main field test, (7) final product. Thiagarajanan (1990: ERIC) stated about four D Model in instructional development, as followed: (1) define, (2) design, (3) develop, (4) disseminate.

The research and development model used in this research was modification model which was adopted from research \& development model of Gall, Borg, and Gall 
and Thiagarajan's front end analysis. Therefore, it is called Martini Jamaris's Research and Development Model, as shown in the following diagram.

\begin{tabular}{|cc|}
\hline Stage 9 & IMPLEMENT/DESSEMINATE \\
\hline Stage 8 & :Field Test 2 \\
Stage 3 & :Model Revision 2 \\
Tahap 2 & :Field Test 1 \\
Stage 5 & $:$ Model Revision 1 \\
\hline Stage 6 & :Develop Model Design \\
Stage 1 & DEFaluation can involve expert judgment \\
\hline Assessment or Prof of Concept or Literature Study
\end{tabular}

Diagram 1. Mrtini Jamaris's Research And Development Model

Based on the diagram above, it can be concluded that the research and development method used to construct the eight types of formal multiple intelligences assessment instruments consisted of ten episodes. However, the episodes can be divided into three stages. First stage was to define which accomplished by doing proof concept and theories of each type of multiple intelligences through cross analysis theories or library research. The result of this activity was used to develop conceptual frame works of formal multiple intelligence assessment instruments for 4-6 years old children. Second stage was to develop assessment instruments of the eight types of multiple intelligences. This stage consisted of: (a) constructing eight types of formal multiple intelligences assessment instruments, (b) doing field test of the eight types of formal multiple intelligences assessment instrument in order to have valid and reliable assessment instruments; (c) implementing the eight types of formal multiple intelligences assessment instruments, in order to know the effectiveness of the instruments in assessing the improvement of the 4-6 years old children's multiple intelligences. Therefore, the third stage was to disseminate the eight types of formal multiple intelligences assessment instruments for the 4-6 years old children which would be conducted in workshop or training.

\subsection{Conceptual Frame Work of the Formal Multiple Intelligences of the 4-6 Years Old Children}

The result of library research was proof theories analysis - synthesis of the 4-6 years old children's multiple intelligences, which was formulated as followed: “The 4-6 years old children's multiple intelligences consist of eigth types of intelligence, as followed: (1) verbal/linguistics intelligence can be identified through the language overt behaviors shown by the children, among them are: (a) enjoy speaking interaction, (b) enjoy telling short or simple story, (c) remember name, place, date, any small thing easily, (d) enjoy reading books, (e) like to spell words, (e) like to listen to the poet, (f) enjoy language games, (g) enjoy listening to the radio, and (h) have good grade in language lesson reading and writing; (2) logical mathematical intelligence can be identified by logical mathematical the children'sovert behaviors, such as, (a) classifying objects, events, and people, (b) arranging objects and events based their order / hierarchy (c) making explanation logically and rasionally, (d) remembering numbers up to 10 easily, (e) calculating numbers up to 10 easily, (f) understanding cause and effect relationship, (g) finding pattrens of objects and events, (h) understanding subtraction $(-+)$ proccess up to 10 easily; (3) visual - spatial intelligence can be identified by overt behavior of the children in doing some activities, such as, (a) picturing ideas in the form of drawing, (b) picturing events and objects detailly, (c) arranging puzzle, (d) picturing people, animals, objects and events in the form of drawing, (d) arranging blocks into three dimensions, (e) understanding picture or illustration of building easily and explain it; (4) bodily -kinesthetic intelligence can be identified by bodily - kinesthetic overt behaviors shown be the children in doing groos motor activities, such as, (a) riding tree wheel cycles or two wheel cycles, (b) running and suddenly stop, (c) climbing, (d) hoping with one foot and two feet, (e) jumping, (f) standing balancely on one foot, (g) walking on bridge or block balancely. as well as, overt behaviors in doing fine motor activities, such as, (a) put on and put off dress; (b) put on and put off drees' buttons, (c) holding paper while another hand writing, (d) folding papers into object shape, (e) taking small thing by using finger edge, (f) cutting thing by using knife or other tools; (g) using spond and fork in eating; (5) intrapersonal intelligence can be identified by overt behaviors of the children, such as, (a) showing abilities in focusing attention during doing some activities (b) showing free or unstressed behaviors in expressing point of view (c) having strong self motivation, (d) showing ability in learning and doing some activities alone, (e) expressing thinking and feeling appropriately, (f) showing ability in self directing toward goal and (g) having some hobies; (6) interpersonal intelligence can be identified by overt behaviors shown by the children, such as, (a) enjoy having some friends, (b) making a lot of social activities, either at school or other place in their environment, (c) familiar with their environment, (d) get involved in various activities at school or out of school, (e) able to take action in overcome conflict or dispute among friends, (f) enjoy to play in team, (g) showing empathy to other feelings, (h) able to take action as counselor for friends, (i) enjoy teaching others, (j) showing leadership ability; (7) musical- rhythmic intelligence can be identified by the musical rythmic children's overt behaviors, such as, (a) remember rhythmic and melody easily, (b) able to match movement to the sound of music and melody, (c) enjoy playing music instruments, (d) able to create rhythmic, (e) enjoy listening to the music; (8) naturalist intelligence can be identified by the children's overt behaviors of the 4-6 years old children toward their environment, such as, (a) enjoy doing environmental conservation, (b) awareness of ecological sustainable, (c) awareness of natural phenomena, and (d) enjoy doing natural observation. 


\subsection{Model of the Formal Multiple Intelligences Asessment Instruments of the 4- 6 Years Old Children}

Asseement is a systematic activities in order to collect information about the development of the children which involved development in field of multiple intelligences. The instruments are tools which are needed in doing assessment of the multiple intelligences. Consequently, it is necessary to develop formal assessment instrument for multiple intelligences of the 4-6 years old children. Martini Jamaris (2009: 58) stated that assessment contain two kinds of activities, namely: measurement and evaluation.

Measurement activity used measurement instrument, such as, instrument assessment to test and to get information about children achievement in their development while evaluation is the activity to compare the result of measurement to the development miles stone. Therefore, based on the both activities the position of the children developmental achievement can be decided. (Woolfolk \& Nicolich, 1980: 506-507, Gay, 1980: 8).

Martini Jamaris (2009: 75-76) describes steps needed to develop formal assessment instrument, as followed: (1) cross theories analysis related to measured variable; (2) synthesis theories of variable measured, which is done based on the result of cross theories analysis; (3) develop indicators of the variable measured; (4) decide assessment parameters which range a long the continum line, such as, from negative to positive, or from worst to best, or from dependent to independent; (5) develop instrument item out lines, (6) write down instrument items, (7) duplicate instrument items based on the amount needed, (8) test validity and reliability of the assessment instrument to the target population, (9) analyze the result of the validity and reliability of the assessment instrument; (10) select unvalid instrument items and take them out of the assessment instrument; (11) count the reliability cooefisien of the assessment instrument, value of reliability coofesient range from $0-1$; (12) use the instrument assessment to assess the children development.

The steps in developing assessment instrument which stated previously were used to construct model of the formal multiple intelligences assessment instruments for 4-6 years old children.

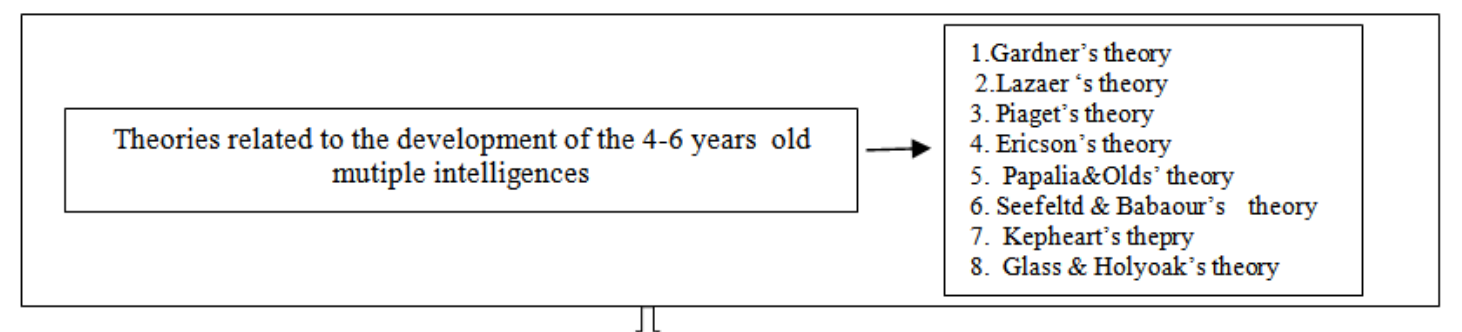

Conceptual definition : conceptual frame works of eigth types of multiple intelligence of the 4-6 years old children

ת

Operational definition : the implementation of the conceptual frame works in the form of gained score of the 4-6 years old children after doing the formal multiple intelligences assessment

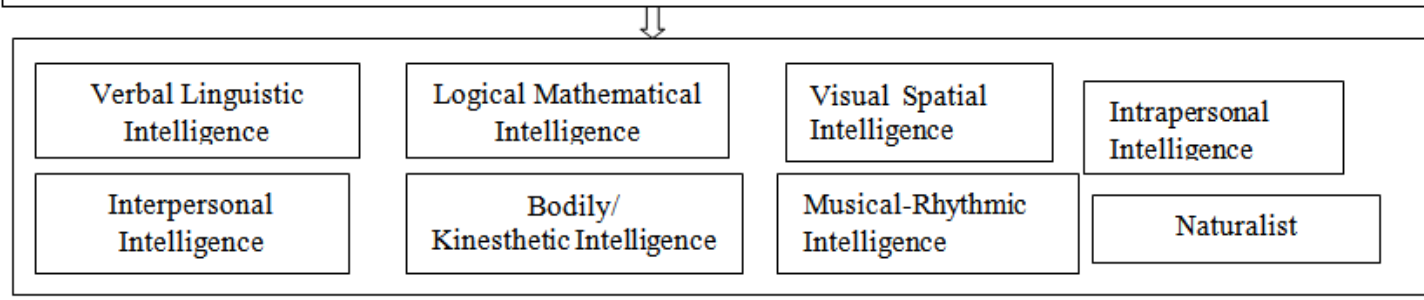

\section{ת}

Ditermining indicators of eight types of the formal multiple intelligences assessment instruments of the 4-6 years old children

\begin{tabular}{l} 
Out lining the eigth types of formal multiple intelligences assesment instruments of the 4-6 years old children \\
$\begin{array}{l}\text { Developing items of eigth types of formal multiple inteligences assessment instruments of the 4-6 years old } \\
\text { children }\end{array}$ \\
$\begin{array}{l}\text { Deciding validity and reliabilty of the eigth types of formal multiple intelligences assessment instruments of the } \\
\text { 4-6 years old children through field test } \\
\text { The formal multiple intelligences assessment instruments of the 4-6 years old children are ready to be used for } \\
\text { assessing instructional processes focused on multiple intelligences of the 4-6years old children }\end{array}$ \\
\hline
\end{tabular}

Diagram 2. Martini Jamaris’s Model of Formal Multiple Intelligences Assessment Instruments for The 4-6 Years Old Children 
Far Bellow Average

\begin{tabular}{|l|}
\hline If show $\leq$ \\
$25 \%$ of \\
indicators of \\
assessment \\
instrument
\end{tabular}

Bellow Average

\begin{tabular}{|l|}
\hline If show \\
$26 \%-50 \%$ \\
of indicators \\
of assessment \\
instrument
\end{tabular}

Average

\begin{tabular}{|l|}
\hline If show \\
$51 \%-75 \%$ \\
indicators of \\
assessment \\
instrument
\end{tabular}

Above Average Far Above Average

If show $76 \%$
$-100 \%$
indicators of
assessment
instrument

If show>

$100 \%$ of indicators of assessment instrument

Measured Standard of Formal Multiple Intelligences Assessment Instruments of the 4-6 Years Old Children

\subsection{Validity and Reliability of the Formal Assessment Instruments of the 4-6 Years Old's Multiple Intelligences}

Field tests of the formal multiple intelligences assessment instruments for 4-6 years old was done in order to test validity and reliability of the assessment instruments. Instrument validity relates to what variables have to be measured. Reliability of the instrument refers to how far the instrument matched to each other after assessment is done, at least two times. In accordance with the criteria of valid amd reliable instrument, the measured standrad of the formal multiple intelligences assessment instruments of the $4-6$ years old children were decided as shiwn in the following rating scale.

The field test of the formal assessment instruments of the 4-6 years old children's multiple intelligences were done twice. First field test was carried out on 20 children. Second field test was involved 40 children. The field tests were conducted at Aisyah Kindergarten No 54, East Jakarta. Indonesia. The both assessment instruments field tests were revealed that the instruments were valid and reliable. The reason underlaied the statement was because with $\sigma 0.05$, $r$ value of all items of the each types of formal multiple intelligences assessment instruments were above $r$ table (table of product moment), as shown in the following table.

Table 1. Validity And Reliability of The Formal Mulitple Intelligences (MI) Assessment Instruments of The 4-6 Years Old Children

\begin{tabular}{|c|c|c|c|c|}
\hline MI Type & First Field Test $\mathrm{n} 20 \sigma 0.05 \mathrm{r}$ table 0.44 & \multicolumn{2}{|c|}{ Second Filed Test $\mathrm{n} 40 \sigma 0.05 \mathrm{r}$ table 0.312} \\
\hline & Validity & Reliability & Validity & 0.835 \\
\hline Verbal/Linguistic Intellience & 0.625 & 0.933 & 0.531 & 0.835 \\
\hline Logical Mathematical Intelligenc & 0.597 & 0.875 & 0.456 & 0.568 \\
\hline Visual Spacial Intelligence & 0.440 & 0.568 & 0.463 & 0.855 \\
\hline Interpersonal Intelligene & 0.514 & 0.870 & 0.547 & 0.917 \\
\hline Intrapersonal Intelligence & 0.599 & 0.586 & 0.602 & 0.877 \\
\hline Bodily/Kinesthetic Intelligence & 0.618 & 0.906 & 0.602 & 0.877 \\
\hline Music/Rhythmic Intelligence & 0.618 & 0.906 & 0.614 & 0.878 \\
\hline Nututalist Intelligence & 0.637 & 0.882 & \\
\hline
\end{tabular}

4.4. Implementation of Formal Multiple Intelligences Assessment Instrument of the 46 Years Old Children

In implementing formal multiple intelligences assessment instruments, especially for the 4-6 years, the mix method research was done in order to have scientific results. The mix method research consisted of two kinds of research methods, they were quantitative research method and qualitative research method. Qualitative method used to study the role of the implementation of integrated learning design used to develop of the 4-6 years old's multiple intelligences. Therefore, observation guide, interview and documentation were used to record the children's multiple intelligences improvement..

Quantitative method used in order to measure the increase or the intensified of the children's multiple intelligences,. In accordance with the need of the mix method research, the eight types of multiple intelligences formal assessment instruments were implemented twice. Firstly, to do pre assessment, and secondly, to do post assessment. Therefore, the assessment instruments were applied before and after the implementation of integrated learning model implementation.

The mix method research used in the form of action research was Martini Jamaris' action research model, as shown in the bellow diagram. 


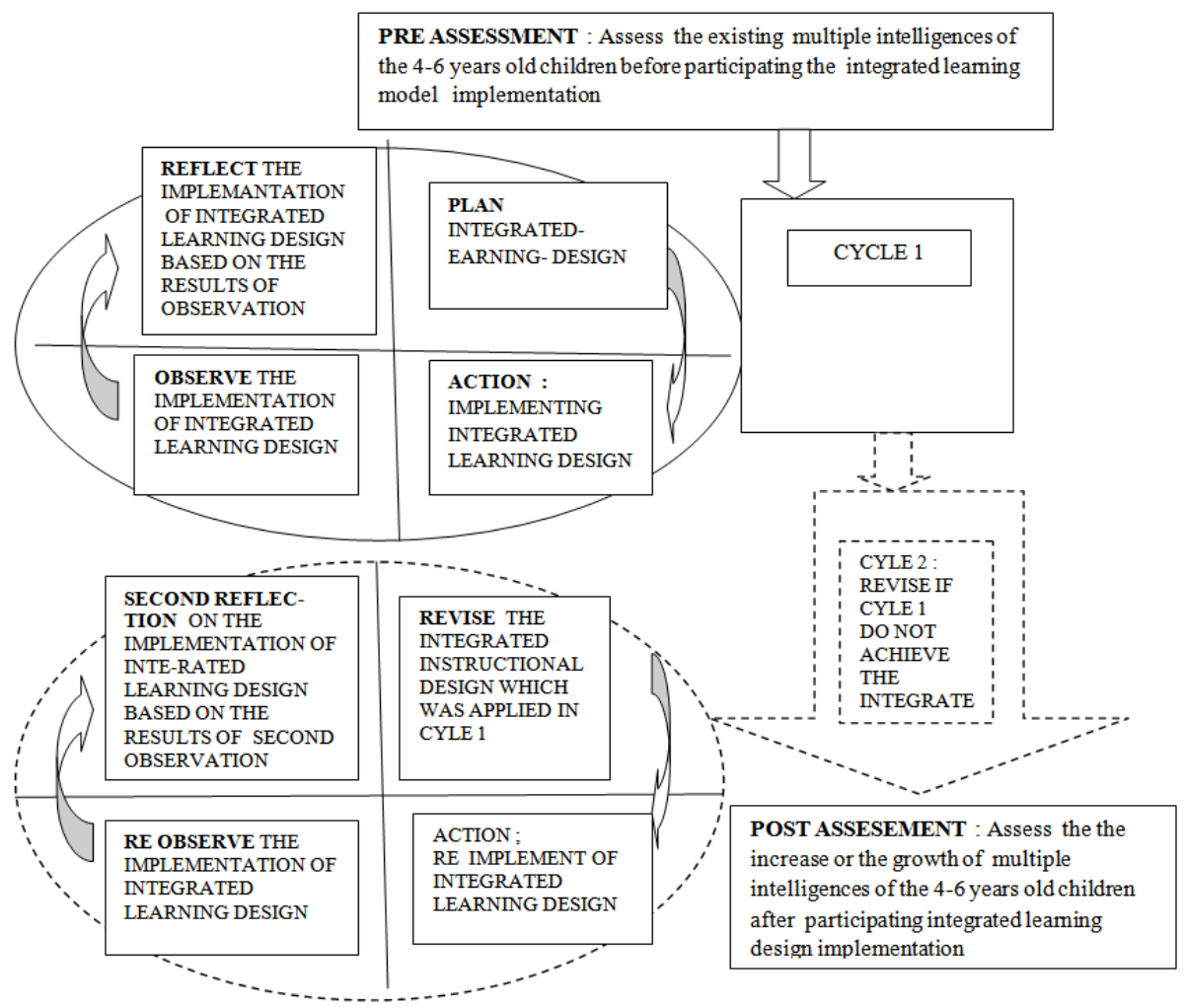

Diagram 3. Martini Jamaris’s Action Research Model

In this research the second cycle was not conducted, it was because the first cycle showed that all of the $4-6$ years old children's mutiple intelligences were improved.

The action research was participated by 15 children, which consisted of 13 normal children and 2 special needs children (1 mentally retarded and 1 behavior problem). The action research was conducted 8 weeks, equal with 40 days and equal with 120 hours. Therefore, the time used for studying the growth of the 4-6 years old's multiple intelligences was matched to the research process.
The integrated instructional model used in this research was constructed based on the result of analysis of instructional system theories, in which, the system at least consisted of instructional objectives, instructional contents, instructional processes, and instructional evaluation (Dick and Carry, 1985: 31, as well as, model of integrated curriculum (Fogarty, 1991:53) and Martini Jamaris (2005:21) leaded the researcher to construct the multiple intelligences integrated instructional model, as shown by diagram 4, as followed:

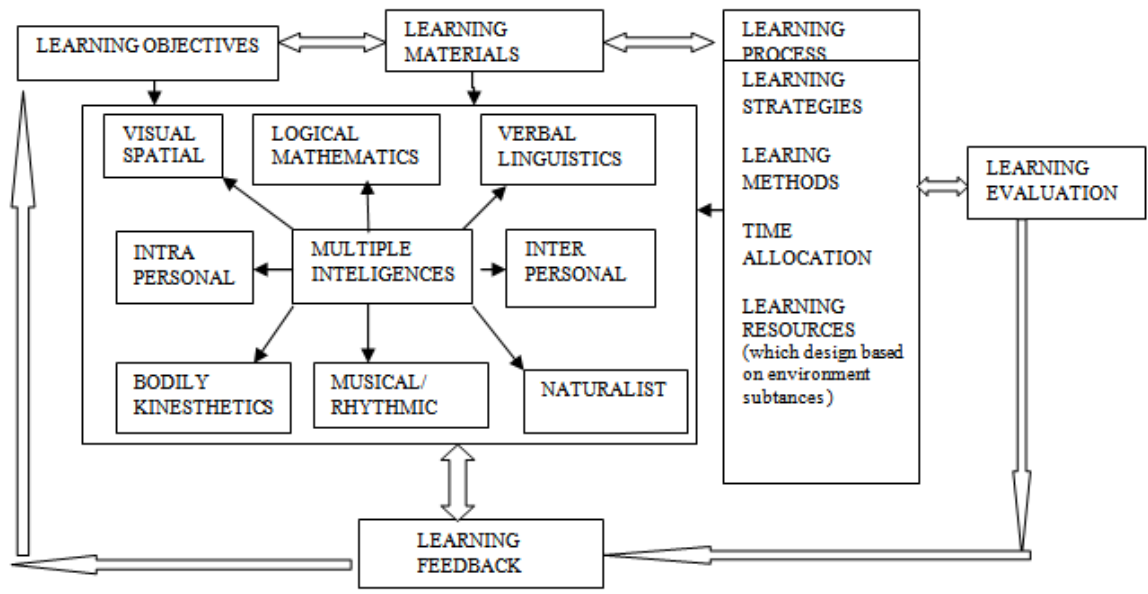

Diagram 4. Martini Jamaris’ Multiple Intelligences Integrated Instructional Model

Integrated instructional model which was used to develop multiple intelligences of the 4-6 years old children was selected carefully, therefore the model matched to the need of the children.

A long with the requirement of integrated instructional model, in which, the researcher adopted Fogarty's webbed model (191: 52-60) and Collins and Hazel (1991: 21), therefore, the instructional process was design in the forms of a theme. The learning theme used during the integrated learning process and learning activities was dealing with environment "water" and it's related issues. as presented in diagram bellow. The reason to select water as a theme of the integrated instructional process was because water was a kinds of substance which always used by the children in their everyday life. 


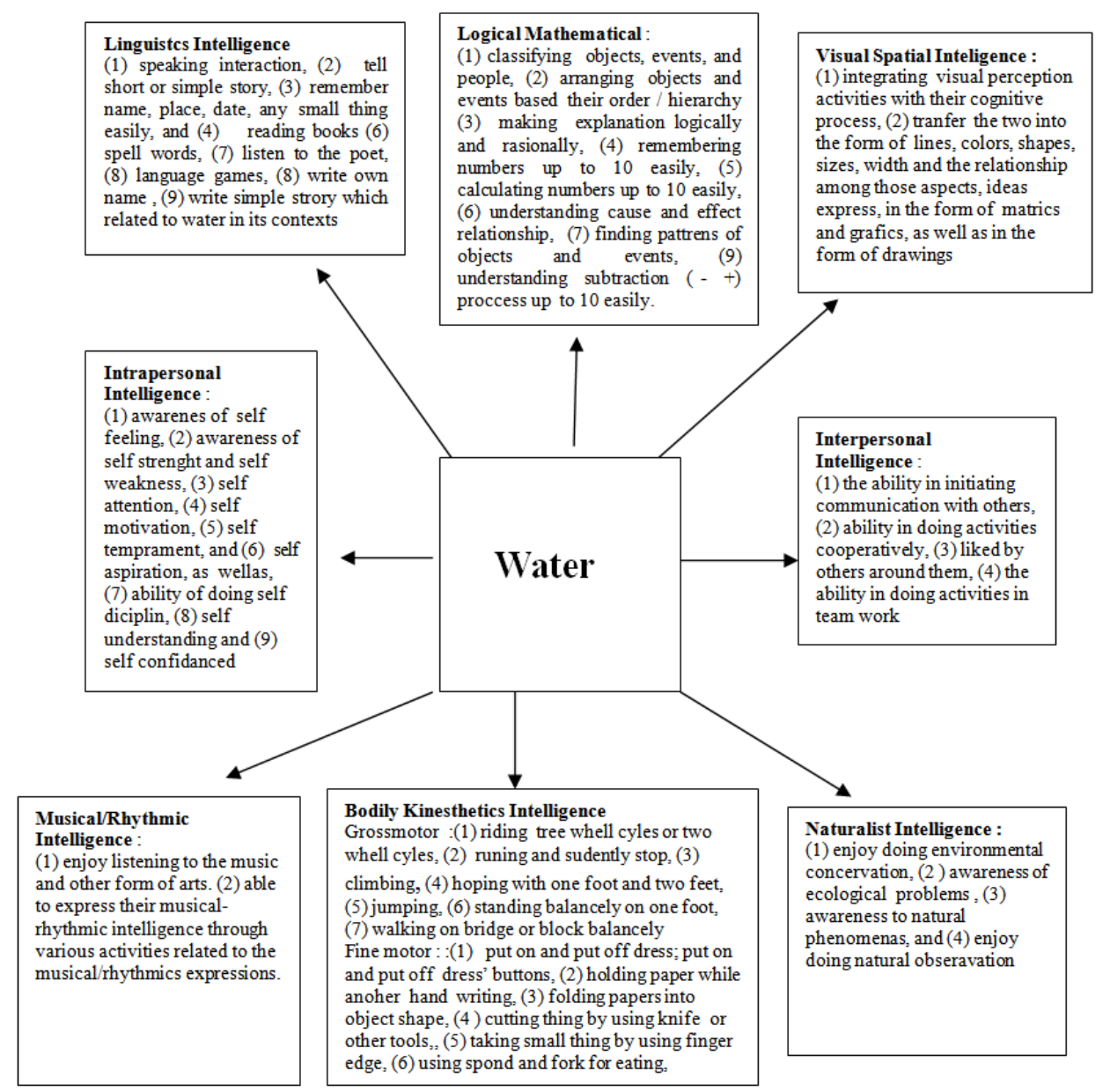

Diagram 5. Martini Jamaris’ Integrated Learning Webbed Model

\subsection{Implementation of the Formal Multiple Intelligences Assessment Instrumens of the 4- 6 Years Old Children}

The action research which was used to implement the formal multiple intelligences assessment instruments of the 4-6 years old children was conducted at Aisyah Kindergarten No 54, East Jakarta. Indonesia. The result of the action research revealed the eigth types of multiple intelligences of the children were increased, as shown in the bellow diagram.

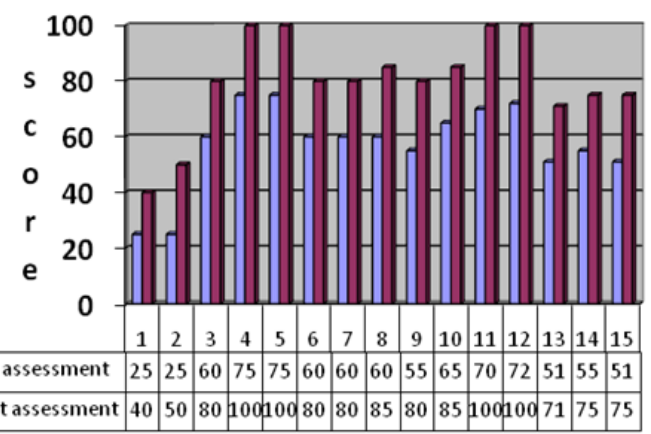

Participants

Diagram 6. Individual Growth of The 4-6 Years Old Children's Multiple Intelligences After Participating Integrated Instructional Model

Based on the above diagram, it could be concluded that the multiple intelligences of the 4-6 years old children were increased after participating the integrated instruction model. Participant no 1 and no 2 were special need children, their score was increased from 25 in pre assessment to 40 and 50 in post assessment. Ten children's multiple intelligences, no 3, 4, 5, 6, 7, 8 9, 10, 11 and 12 categorized as above average, while multiple intelligences of children no 13, 14, and 15 categorized as normal. Even though, there were two children reached score below normal, it did not mean that the assessment instruments were not success to measure their improvement because their limitation make them get limited improvement. Therefore, the formal multiple intelligences assessment instruments assessed the improvement of the 4-6 years old children's multiple intelligences accurately.

In order to have a comprehensive understanding about the multiple intelligences of the 4-6 years old children before and after they went through the integrated instructional model, therefore, the scores of the each type of the multiple intelligences of the children before and after participating the integrated learning process were also presented, as shown in diagram 7 bellow

Based on the scores of the eight types of multiple intelligences of the 4-6 years old children before and after they went through the integrated instructional model implementation, it concluded that the children's multiple intelligences improved 23.13\%. It was taken from the result of the pre assessment average score which was 61.20 and the post assessment average score which was 75.35 . 


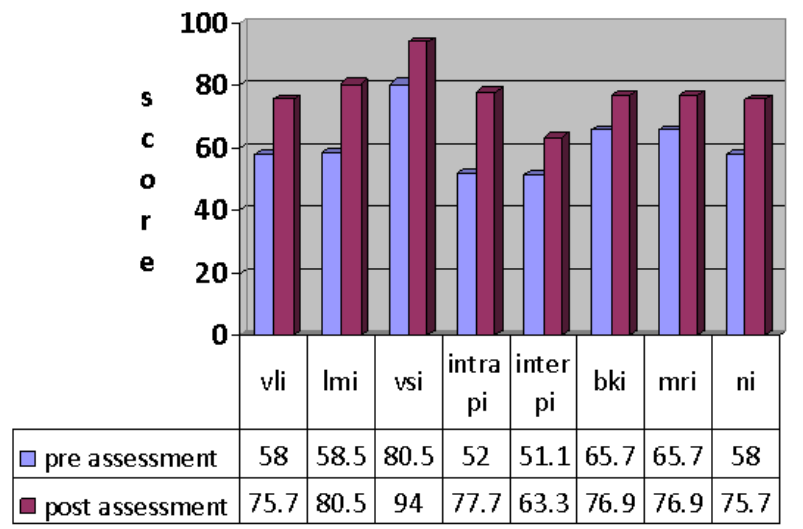

multiple intelligences

Diagram 7. The 4-6 Years Old Children's Multiple Intelligences Before and After Participating Integrated Instructional Model

vli = verbal linguistic intelligence, $\operatorname{lmi}$ =logical mathematical intelligence, vsi =visual spatial inteligence, intrepid =intrapersonal intelligence, interpi = interpersonal intelligence, bki = bodily kinesthetic intelligence mri $=$ musical rhythmic intelligence, $\mathrm{ni}=$ natutralist

\section{Discussion}

Judging from the research and development ( $\mathrm{R}$ and $\mathrm{D}$ ) model used to produce the formal multiple intelligences assessment instruments for the 4-6 years old, in which, it took two years to develop the assessement instruments and followed by the instruments implemented carefully and accurately. It was because The $\mathrm{R}$ and $\mathrm{D}$ model was implemented through three stages, as followed: the first stage was literature research aiming to analyze and synthesis concepts, principles, and theories which was used to formulte the conceptual frameworks of the 4-6 years old children's multiple intelligences; the second stage was to design/ develop the eight types of formal multiple intelligences assessment instruments of the 4-6 years oldchildren, which consisted of: (1) to design / develop the valid and reliable of the neight types of formal multiple intelligences assessmenent instruments of the 4-6 years old; (2) to do field test in order to have valid and reliable formal multiple intelligences assessment instruments, firstly was carried out on 20 children and secondly, involved 40 children. The both field tests were revealed that the assessment instruments of the eight types of formal multiple intelligences of the 4-6 years old children were valid and reliable (see table 1); the third episode was to apply the intelligences assessment instruments in assessing the improvement of the 4-6 years old's multiple intelligences after participating the integrated instructional processes which focused on the improvement of children's multiple intellegences. The study was done through mix method research and revealed that all of the children's individual multiple intelligences were improved $41 . \%$ after participating the integrated instructional processes (see diagram 4). Detailed infromation of the improvement of multiple intelligences of the 4-6 years old children can be seen in the improvement of each tytpe of multipleikntelligences of the 4-6 years oldchildren (see diagram 5). Eventhough, the average score were lower than average indivdual improvement scores, it did not mean that the integrated instructional model was not effective to improve the children multiple intelligences because in the group of the children, there were two special need children. One child was mentally retarded and another child was behavior problem. Consequently, their improvement influenced the avarege score of multiple intelligences of the all 4-6 years old. Therefore, there was no point to say that the formal multiple intelliegnces assessment instrument s of the 4-6 years old children were not effective to assess the improvement of the children multiple inteligences improvement because the formal multiple intelligences assesment instruments of the 4-6 years old children assessed the improvement of the multiple intelligences of the children accurately.

\section{Conclusion}

Based on the research findings, it could be concluded that multiple intelligences of the early aged children, especially the 4-6 years old children were developed carefully and conducted a long with the scientific research procedures. Starting from doing cross teories analysis, which used to construct conceptual frameworks of the -4-6 years old's multiple intelligences. These activities followed by developing the eight types of formal multiples intelligences assessment instruments of the -4-6 years old children. The instruments went through field test twice, the first test was carried out on small group which consisted of 20 children, the second test involved 40 children. Both of the field tests were revealed that the eight types of the multiple intelligences assessment instruments were valid and reliable. On the top of these the assessment instruments was, implemented to assess the improvement of the 4-6 years old's multiple intelligences after participating the integrated instructional model which focused on the improvement of the children's multiple intelligences. In accordance with the research procedures, the mix method research was applied in the form of action research, which, participated by 15 children, age 4-6 years old children. Even though, the participants of the research were limited, because it was a case study. However, the mix method research was conducted about 8 weeks, equal with 40 days and equal with 120 hours. Therefore, time used to study the growth of the 4-6 years old's multiple intelligences was matched to the need of the action research. Based on the assessment instruments implementation result, it could be concluded that the children's multiple intelligences was increased 23.13\%. Consequently, the assessment instruments were ready to disseminate through training or worksshop, or other kinds of related activities.

\section{References}

[1] Arnold Lewis Glass \& Keith Jamaes Holyoak. Cognition.. McGraw-Hill Book Company. London. 1986, 140

[2] Anita E. Woolfolk \& Loraine McCune Nicolich. Educational Psychology for Teachers. Prentice Hall Inc EnglewodCliff. New Jersey. 1984, 53

[3] W.R. Borg \& Gall. M.D. Educational Research and Development. Longman. New York. 1983, 251-258.

[4] Carol Seefeldt \& Nita Barbaour. Early Childhood Education. MacMillan Colege Publishing Company. New York. 1994, 32-34.

[5] Craig A. Merteler. Action Research: Teachers as Researchers in the Classroom. Sage. Los Angeles. 52. 
[6] David Lazaer. Development of Multiple Intelligences. McMillan, Inc. New York. 2000, 7.

[7] Deanna L. Gooch. Research, Development and Validation of A school Leader's Resource Guide for Facilitation of Social Media Use by School Staff. Kansas State University. Manhattan. 2012.

[8] Diane E. Papalia \& Sally Wendkos Olds. (1995). Human Development. Mc-Hill Book Company.USA. 1986, 237.

[9] Diane E. Papalia \& Sally Wendkos Olds (1985). Psychology. McGraw-Hill Book Company. USA, 222-420.

[10] Howard Gardner. Frame of Mind: The theory of multiple intelligences.: Basic Book. New York.1983, xii-xiii, 67-79.

[11] Jean Piaget. The Realm of the Child. Peacock. New York. 1972, 60.

[12] Jean Piaget. The Equilibration of Cognitive Structures. University of Chicago Press Chicago, IL. 1985, 49-91.

[13] John W Santrock. Child Development. Brown \& Benchmark Publishers. Chicago. 1996, 378.

[14] John W. Creswell. Educational Research: Planning, Constructing and Evaluating Quantitative and Qualitative Research. Upper Sadle River. Columbus, Ohio. 2008.

[15] Kepheart. Learning Disabilities. Brown \& Benchmark Publishers. Chicago. 1976, 15-17.

[16] Kuebler R. Roy \& Smith. Jr Harry. Statistics: John Wiley \& Sons, Inc. New York. 1980

[17] L.R. Gay. Educational Evaluation and Measurement: Competencies for Analysis and Application.: A Bell \& Howell Company. Columbus, Ohio. 1980, 175-177.

[18] Margaret Carr (2003). Assessment in Early Childhood Settings. Sage Publications. London-Thousand Oaks-New Delhi. 2003, 123-124.

[19] Martini Jamaris.. Orientasi Baru Dalam Psikologi Pendidikan Yayasan Penamas Murni. Jakarta. 2011, 42-43.
[20] Martini Jamaris. Kesulitan Belajar: Perspektif, Asesmen dan Penanggulangannya: Yayasan Penamas Murni.. Jakarta. 2009, 7576.

[21] Martini Jamaris. Pengembangan Multile Intelligences dan Aplikasinya Melalui Pembelajaran Terpadu di Taman KanakKanak. Jurnal Pendidikan dan Kebudayaan. Maret 2005. No 053 Tahun ke 11, pp. 177-206.

[22] Martini Jamaris. Pengembangan Kemampuan Koordinasi Motorik Kasar Dan Halus Anak Usia Taman Kanak-Kanak. Jurnal Pendidikan Anak Usia Dini. 2003 Vol 1. No 1. Januari 2003, pp 40-61.

[23] Martini Jamaris. Pendidikan Anak Sejak Usia Dini Sebagai Usaha Kongkrit Dalam Mempersiapkan Aset Bangsa di Masa Depan. (Orasi Ilmiah). Jakarta: UNJ 2005, 21.

[24] Martini Jamaris, Delvi Eliza, Wuryani dan Trisna Mulyeni. Profil Kecerdasan Jamak Anak Usia 4-5 Tahun.s PPs UNJ. Jakarta, 2012, 96-97.

[25] Michael Pohl (2000). Learning to Think and Thinking to Learning: Hawker Brownlow Education.. Australia. 2000, 49.

[26] Naughton Mac, Glenda, Rolfe A. Sharne \& Blatchford Siraj. Iram. Doing Early Childhood Research. Allen Unwin. Craws Nest. Australia. 2001, 168.

[27] Robin Fograty. How to Integrate Curricula. Colombia University Teachers College. New York, 1991, 67.

[28] Sivasailam Thiagarajan. Performance Technology and Instructional Design. ERIC: Educational Technology, 1990.

[29] Sue Clark Wortham. Measurement and Evaluation in Early Childhood Education. New Jersey: Merril an imprint of Prentice Hal. 1992, 20.

[30] Vasta Ross, Haith M. Marshall \& Miller A. Scott. (1999.) Child Psychology. New York: John Weley \& Sons, Inc. New York, 1999, 237. 